\title{
Comparison of Blue Basin Traps on Capturing The Adults of Tropinota hirta (Poda, 1761) (Coleoptera: Cetoniidae) at Three Different Heights in Cherry Orchards
}

Kiraz Bahçelerinde Farklı Yükseklikte Tropinota hirta (Poda, 1761) (Coleoptera: Cetoniidae) Erginlerini Yakalamada Mavi Leğen Tuzakların Karşılaştırılması

\author{
Ali ÖZPINAR ${ }^{*}$, Ali Kürşat ŞAHİN², Burak POLAT ${ }^{3}$
}

\begin{abstract}
In this study, the effect of five different hues of blue colored basin traps at different heights on capture rates of Tropinota (Epicometis) hirta (Poda, 1761) (Coleoptera: Cetoniidae) adults in a cherry garden in Çanakkale (EzineAkköy) province, was investigated. Basin traps, which were painted with blue colors coded as \#B4C8E1, \#C4D5E3, \#A6CDE3, \#4D9AC9 and \#05467A, and made from 35x25x15 cm sized basins, were used to capture $T$. hirta adults. The trial was conducted on a 21 da cherry orchard with 5 years old Regina cultivar trees on Maxima 14 rootstock. It was planned with three repetitions, traps were mounted on platforms on wooden stakes placed between two trees with $10 \mathrm{~m}$ space with other traps at three different heights as; on ground level $(0 \mathrm{~cm})$, on $50 \mathrm{~cm}$ and $100 \mathrm{~cm}$ from ground level, on 22 March, 15 days before the trees bloomed with a total of 45 traps. The basin traps were filled with $1 / 3$ of water and licensed attractants (100 mg Trans-Anethol $+100 \mathrm{mg}$ Cinnamyl Alcohol) are added to the traps. The samplings were done with an interval of 2 days and the adults caught in the traps were recorded. The adult flight period was determined from the number of $T$. hirta adults caught in different blue colored traps at three heights. A total of 3828 adults were captured in all traps. $73.45 \%$ of the total adults caught in the traps were found before flowering period (before April $7^{\text {th }}$ ). The difference between the numbers of adults caught in traps at three heights was statistically significant. Highest number of adults was caught on the ground level ( 0 $\mathrm{cm}$ ) in the \#C4D5E3 code trap (429 adults) and this trap was followed by the trap \#B4C8E1 at $50 \mathrm{~cm}$ height (384 adults). The number of adults caught by all traps at $100 \mathrm{~cm}$ height was lower than the other two heights. As a result, traps color and heights were found to be different in catching $T$. hirta adults in cherry orchard. With these results in mind, there is a strong possibility to use \#C4D5E3 coded traps (Light grayish blue) successfully in cherry orchards against $T$. hirta adults in the future.
\end{abstract}

Keywords: Cherry, Tropinota hirta, Epicometis, Blue basins traps, Different heights

\footnotetext{
1*Sorumlu Yazar/Corresponding Author: Ali Özpınar, Çanakkale Onsekiz Mart University, Faculty of Agriculture, Department of Plant Protection 17100, Çanakkale, Turkey .E-mail: aozpinar@comu.edu.tr (D) OrcID: 0000-0003-4512-8027

2 Ali Kürşat Şahin, Çanakkale Onsekiz Mart University, Faculty of Agriculture, Department of Plant Protection 17100, Çanakkale, Turkey .. E-mail: aksahin@comu.edu.tr (D) OrcID: 0000-0002-2721-8822.

${ }^{3}$ Burak Polat, Çanakkale Onsekiz Mart University, Faculty of Agriculture, Department of Plant Protection 17100, Çanakkale, Turkey .. E-mail: bpolat@comu.edu.tr (iD) OrcID: 0000-0001-9171-1024

Atıf/Citation: Özpınar, A. Şahin, A.K., Polat, B.. Comparison of Blue Basin Traps on Capturing the Adults of Tropinota hirta (Poda, 1761) (Coleoptera: Cetoniidae) at Three Different Heights in Cherry Orchards. Tekirdağ Ziraat Fakültesi Dergisi, 18 (4), 739-747

CBu çalışma Tekirdağ Namık Kemal Üniversitesi tarafından Creative Commons Lisansı (https://creativecommons.org/licenses/by-nc/4.0/) kapsamında 


\section{$\overline{\mathbf{O} z}$}

$\mathrm{Bu}$ çalışmada Çanakkale (Ezine -Akköy) ilinde, kiraz bahçesinde mavi rengin beş farklı tonundaki leğen tuzaklara üç farklı yükseklikte yakalanan Tropinota (Epicometis) hirta (Poda, 1761) (Coleoptera: Cetoniidae) ergin sayıları karşılaş̧ııılmıştır. Boyutları 35x25x15 cm olan şeffaf leğenler, \#B4C8E1, \#C4D5E3, \#A6CDE3, \#4D9AC9 ve \#05467A kodlu mavi renk boyalar ile boyanmış ve $T$. hirta erginlerini yakalamada kullanılmıștır. Deneme Maxima 14 yarı bodur anaç üzerine aşılı 5 yaşındaki Regina kiraz çeşidi ile tesis edilmiş 21 dekarlık üreticiye ait bahçede yürütülmüştür. Deneme üç tekrarlı olarak planlanmış, ağaçlar çiçek açmadan önce, 22 Mart'ta leğen tuzaklar 10 m aralıklarla 2 ağaç arasına gelecek şekilde üç farklı yükseklikte $(0 \mathrm{~cm}, 50 \mathrm{~cm}$ ve $100 \mathrm{~cm})$ yerleştirilmiş olup, bu amaçla toplam 45 leğen tuzak kullanılmıștır. Leğenler 1/3 oranında su ile doldurulmuş ve üstten geçirilen iplerle etrafına çakılan demir çubuklara (yerdeki tuzaklar) ve çivilere (ahşap sehpalar) sabitlenmiş ve cezbedici (100 mg Trans-Anethol +100 mg Cinnamyl Alcohol) leğenlere monte edilmiştir. Örneklemeler 2 gün arayla gerçekleştirilmiş ve tuzaklarda yakalanan erginler kaydedilmiştir. Ergin uçuş periyodu üç farklı yükseklikte farklı mavi renklerdeki tuzaklarda yakalanan ergin sayılarıyla belirlenmiştir. Tüm tuzaklarda toplam 3828 ergin yakalanmıştır. Tuzaklarda yakalanan tüm erginlerin \%73.45'inin çiçeklenme öncesi (7 Nisan'dan önce) döneme ait olduğu görülmüştür. Farklı yüksekliklerde tuzaklarda yakalanan ergin sayıları arasındaki fark istatistiksel olarak önemli bulunmuştur. En yüksek ergin sayısı yer seviyesindeki $(0 \mathrm{~cm})$ \#C4D5E3 kodlu tuzakta (429 adet) yakalanmış ve bu tuzağı $50 \mathrm{~cm}$ yükseklikteki \#B4C8E1 kodlu tuzak (384 adet) izlemiştir. $100 \mathrm{~cm}$ yükseklikte yer alan bütün tuzaklarda yakalanan erginlerin sayısı diğer yüksekliklere göre daha düşük çıkmıştır. Sonuç olarak kiraz bahçesinde $T$. hirta erginlerini yakalamada tuzak ve yüksekliklerin etkinliği farklı bulunmuştur. Bu bulgulara göre kiraz bahçelerinde $T$. hirta erginlerini yakalamada \#C4D5E3 kodlu açık mavi renk leğen tuzakların başarılı olarak kullanacağı kanısına varılmıştır.

Anahtar kelimeler: Kiraz, Tropinota hirta, Epicometis, Mavi leğen tuzaklar, Farklı yükseklikler 


\section{Introduction}

Turkey is in the first place in the world with the production of Cherry, which is one of the most important commercial fruits in the world, with a quantity of 639.564 tonnes (Doğan Öz and Saner, 2021). Çanakkale province has an important potential for cherry production. In cherry production, control measurements against the pests start in the flowering period. One of these pests, Tropinota (Epicometis) hirta (Poda, 1761) (Coleoptera: Cetoniidae) were identified in many regions of Turkey on pome and stone fruits (Kara, 1992, Kaya and Kovanc1, 2004; Yaşar et al., 2013; Arslan and Aslan, 2015; Gezer and Özpınar, 2015). Adults of T. hirta are pests that damage the flowers of fruit trees by feeding on the flowers and polen (Özbek, 2008). According to the interviews with the farmers in Çanakkale, damage of $T$. hirta is tolerable on peach and apple trees with fruit thinning, but it is important in cherry production. A study carried out in Bulgaria showed that T. hirta can cause damage on cherry trees up to $70 \%$ (Kutinkova and Andreev, 2004).

Because of the potential damage on honeybees and other pollinator insects in blooming period, usage of chemical control applications is limited against the adults of $T$. hirta. Instead, using colored traps and attractants for mass capturing of adults is accepted as an alternative control method (Vuts et al., 2010). Previous studies have shown that blue was more effective in capturing the adults than other colors (Schmera et al., 2004). Nonetheless, studies to determine the suitable color for the fruit species continue. For example, while white is more attractive in blooming period in cherry and sour cherry, blue is better at capturing adults after blooming period (Aydin, 2011). Also, the shape of the traps seems to have an effect on the success of the trap. According to the studies by Sağdaş (2011) and Arslan and Aslan (2015), blue funnel traps were found to be more successful in Isparta, while blue basin traps were better in Çanakkale (Gezer and Özpınar, 2015).

On the other hand, it was reported that capturing adults of $T$. hirta was more successful when a mixture of cinnamyl alcohol and trans-anethole was used as the attractant (Toth et al., 2003) and the success of light blue traps were increased (Schmera et al., 2004). Also, an important increase in the number of captured adults was recorded by adding $[(E)$-anethol ve $(E)$ - cinnamyl alcohol at 1:1 ratio] into the aforementioned attractant mixture (Vuts et al., 2010). Also, 5 different hues of blue were examined by Yaşar et al., (2013) and they concluded that the best result was obtained from the funnel traps with \#C6DEFF hexadecimal code in cherry and from the basin traps with \#4D9AC9 code in peach (Erbay and Özpınar, 2019). It is observed that, the color of the flowers is an important factor in capturing the adults of $T$. hirta.

Based on these studies, we investigated the effectiveness of basin traps with 5 different hues of blue according to their hexadecimal codes, which were shown to be effective at capturing the adults of $T$. hirta (Erbay and Özpınar, 2019; Özpınar and Erbay, 2020), on three different heights by adding a licensed attractant in cherry production areas of Ezine, Çanakkale.

\section{Materials and Methods}

The study was conducted on a 21 da cherry orchard with 5 years old Regina cultivar trees on Maxima 14 rootstock with $5 \times 5$ planting plan in Ezine (Akköy) district of Çanakkale (39 $49^{\prime} 08.20^{\prime \prime} \mathrm{N}$ and 26 20'43.19"E).

Basin traps, which were painted with blue colors coded as \#B4C8E1, \#C4D5E3, \#A6CDE3, \#4D9AC9 and

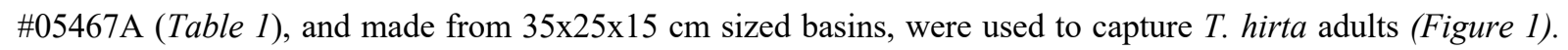
Holes were drilled on basins on 3 sides at $10 \mathrm{~cm}$ depth, to drain excess rainwater. Traps were mounted on platforms on wooden stakes placed between two trees with $10 \mathrm{~m}$ space with other traps at three different heights as; on soil surface $(0 \mathrm{~cm})$, on $50 \mathrm{~cm}$ and $100 \mathrm{~cm}$ from soil surface, according to Özpınar and Erbay (2020).

Table 1. The color mixture values (RGB) and hexadecimal codes of basin traps used to capture Tropinota hirta adults

\begin{tabular}{lccccc}
\hline & Light steel blue & Light grayish blue & Very soft blue & Moderate cyan & Dark blue \\
\hline Hexadecimal codes & \#B4C8E1 & \#C4D5E3 & \#A6CDE3 & \#4D9AC9 & \#05467A \\
Red green blue (RGB) & 180.200.225 & 196.213.227 & 166.205.227 & 77. 154.201 & 5.70 .122 \\
\hline
\end{tabular}

Different height applications were not next to each other (Figure 1). The experiment was designed as random block design and there were 3 empty tree lines between each application line with three repetitions. A total of 45 basins were used with 5 basins per height application. 
Özpinar \& Şahin \&Polat

Basins were immobilized by placing and binding $15 \mathrm{~cm}$ nails on 4 sides of the basins at 50 and $100 \mathrm{~cm}$ heights and iron rods on 4 sides of the soil surface basin with ropes to prevent the effect of wind on the basins. Attractants (100 mg Trans-Anethol+100 mg Cinnamyl Alcohol) were tied to the traps without touching water (Figure 1). Basins were filled with water in $1 / 3$ ratio to prevent adults from climbing out of the traps and evaporated water was added during samplings. The samplings were started on 24.03 .2019 and adults were counted by collecting them with a sieve every two days. Samplings were ended on 03.05.2019 with the declining number of adults in traps. Also, flowering rate (\%) of trees were calculated by counting the number of broken and unbroken buds on branches. Climate data was gathered from the closest climate station of Çanakkale Directorate of Provincial Agriculture and Forestry.

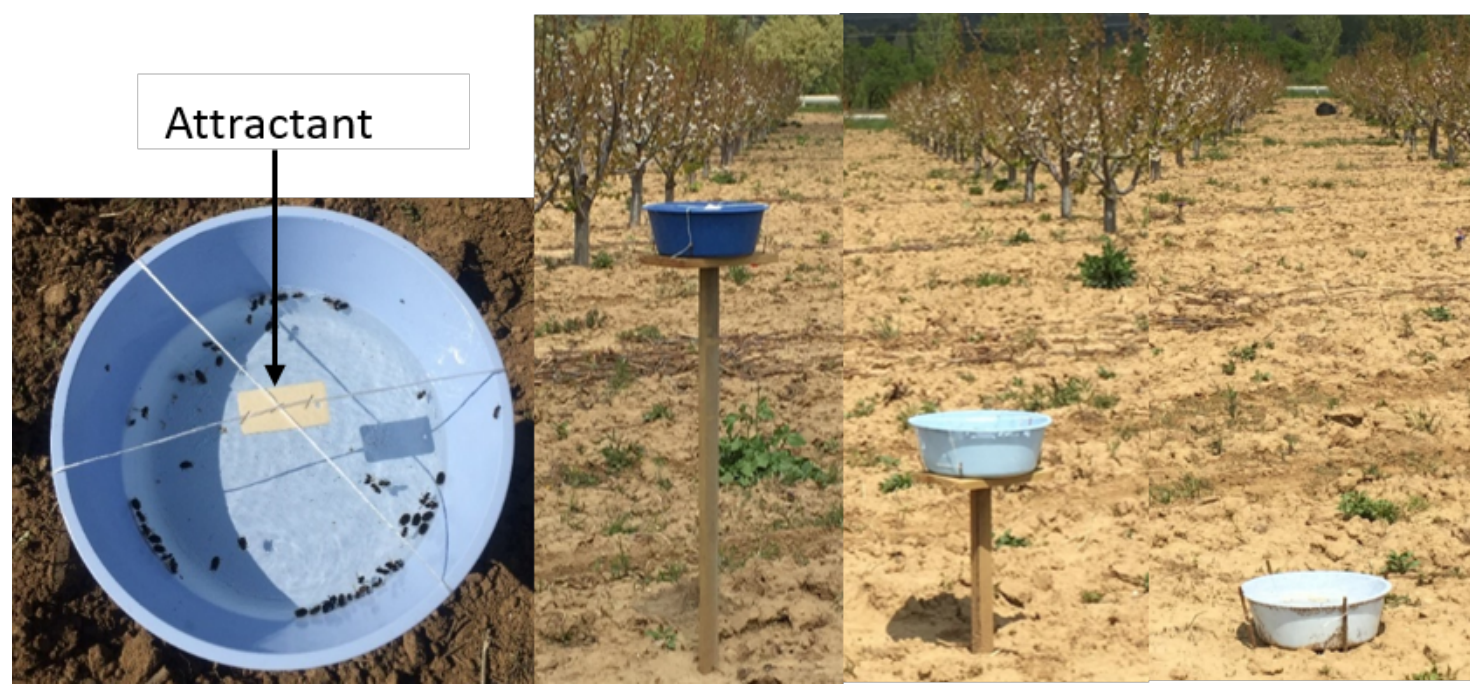

Figure 1. Basin traps on different heights in the cherry orchard

Adult flight of $T$. hirta was determined from the data of basin traps with 5 different hues of blue on three different heights. Also, number of $T$. hirta adults captured in blue basin traps on three different heights were analyzed with 2-way repeated measures ANOVA (SPSS 25) and the means were compared with the Duncan multiple test $(\mathrm{P} \leq 0.05)$.

\section{Results and Discussion}

A high number of adults were captured in the traps with three different heights on 24.03.2019 with a mean daily temperature of $11.9^{\circ} \mathrm{C}$ (Table 2 and Figure 2). According to Gezer and Özpınar (2015) first T. hirta adults were captured in traps on April $2^{\text {nd }}$ of 2013 and March $23^{\text {rd }}$ of 2014 in relation to environmental temperature. In Isparta region, first T. hirta adults were found in traps on March $23^{\text {rd }}$ (Güvenç and Yaşar, 2014) and on March $26^{\text {th }}$ (Yaşar et al., 2013). In another study in Bulgaria, first adults were captured in traps at the end of March and the highest numbers were determined in mid-April (Subchev et al., 2011).

In this study, the highest number of adults were captured in the second sampling date, 26.03.2019. High number of adults in traps showed that adult flight period starts earlier in this region. Another study reported that $T$. hirta adults were first captured on March $2^{\text {nd }}$ and the highest number of adults was in March $18^{\text {th }}$ in a peach orchard in close proximity to our study orchard (Erbay and Özpınar, 2019), supporting this observation.

Because of the overcast weather and rain, adult numbers in traps were lower in the following samplings. In contrast, the number of adults in sunny and warm days was high. Similarly, Zobar and Kivan (2019) reported that Capnodis tenebrionis adults were more caught in traps at high temperatures. This situation caused short-term fluctuations in the number of adults in traps. Thus, no parallels between $T$. hirta adult population density and flowering density of trees were discovered. Flowering period has started on April $7^{\text {th }}$ and has reached to $100 \%$ between April $20^{\text {th }}$ and April $27^{\text {th }}$. The number of adults was low in these dates because of rain. A total of 3828 adults were captured in all traps. It was found that, $73.45 \%$ of the adults captured in the traps in the cherry orchard 
was from pre-flowering period (Before April $7^{\text {th }}$ ). According to Erbay and Özpınar (2019), the number of adults in traps has reached to the highest point on the same date with flowering also reaching to $100 \%$. The high number of adults in the cherry orchard in pre-flowering period is interpreted as adults feeding on flower buds. Likewise, this situation is evaluated as such in many other studies.

Table 2. Number of Tropinota hirta adults captured at three different heights and 5 different hues of blue

\begin{tabular}{|c|c|c|c|c|c|c|c|c|c|c|c|c|c|c|c|c|}
\hline \multirow{2}{*}{$\begin{array}{l}\text { Codes } \\
\text { Height } \\
\text { (cm) } \\
\end{array}$} & \multicolumn{3}{|c|}{ \#B4C8E1 } & \multicolumn{3}{|c|}{ \#C4D5E3 } & \multicolumn{3}{|c|}{ \#A6CDE3 } & \multicolumn{3}{|c|}{ \#4D9AC9 } & \multicolumn{3}{|c|}{ \#05467A } & \multirow[t]{2}{*}{ Total } \\
\hline & 0 & 50 & 100 & 0 & 50 & 100 & 0 & 50 & 100 & 0 & 50 & 100 & 0 & 50 & 100 & \\
\hline 24.03.19 & 33 & 45 & 6 & 45 & 21 & 9 & 57 & 33 & 6 & 54 & 36 & 6 & 24 & 18 & 6 & 399 \\
\hline 26.03.19 & 45 & 78 & 60 & 72 & 90 & 36 & 51 & 45 & 45 & 36 & 54 & 39 & 30 & 39 & 27 & 747 \\
\hline 28.03.19 & 9 & 12 & 0 & 18 & 15 & 3 & 6 & 12 & 3 & 9 & 6 & 6 & 6 & 9 & 0 & 114 \\
\hline 30.03.19 & 3 & 3 & 0 & 6 & 6 & 0 & 3 & 0 & 0 & 0 & 3 & 0 & 3 & 3 & 3 & 33 \\
\hline 01.04.19 & 27 & 42 & 9 & 63 & 30 & 6 & 60 & 36 & 15 & 57 & 60 & 9 & 21 & 9 & 9 & 453 \\
\hline 03.04.19 & 27 & 42 & 6 & 60 & 27 & 12 & 36 & 27 & 6 & 42 & 30 & 3 & 27 & 21 & 12 & 378 \\
\hline 05.04.19 & 33 & 51 & 15 & 54 & 42 & 27 & 33 & 48 & 21 & 48 & 36 & 21 & 33 & 30 & 21 & 513 \\
\hline 07.04.19 & 9 & 27 & 15 & 12 & 9 & 6 & 6 & 6 & 6 & 21 & 18 & 6 & 3 & 9 & 3 & 156 \\
\hline 11.04 .19 & 33 & 45 & 12 & 42 & 30 & 18 & 24 & 30 & 15 & 45 & 33 & 3 & 27 & 12 & 9 & 378 \\
\hline 13.04.19 & 3 & 0 & 0 & 3 & 0 & 0 & 6 & 3 & 0 & 9 & 3 & 0 & 3 & 0 & 3 & 33 \\
\hline 15.04 .19 & 6 & 6 & 0 & 12 & 6 & 3 & 3 & 15 & 6 & 12 & 21 & 3 & 9 & 6 & 9 & 117 \\
\hline 17.04.19 & 6 & 9 & 9 & 12 & 6 & 3 & 6 & 24 & 9 & 6 & 15 & 6 & 3 & 3 & 3 & 120 \\
\hline 19.04.19 & 6 & 0 & 3 & 6 & 3 & 3 & 3 & 0 & 0 & 3 & 3 & 3 & 0 & 3 & 0 & 36 \\
\hline 21.04.19 & 3 & 9 & 3 & 6 & 9 & 3 & 3 & 9 & 0 & 6 & 6 & 3 & 3 & 0 & 0 & 63 \\
\hline 23.04.19 & 3 & 3 & 3 & 0 & 9 & 3 & 3 & 9 & 3 & 0 & 6 & 6 & 0 & 0 & 3 & 51 \\
\hline 25.04.19 & 6 & 3 & 9 & 3 & 9 & 3 & 3 & 9 & 6 & 9 & 9 & 6 & 3 & 0 & 3 & 81 \\
\hline 27.04.19 & 6 & 3 & 6 & 6 & 6 & 0 & 6 & 3 & 6 & 3 & 3 & 9 & 3 & 3 & 3 & 66 \\
\hline 29.04.19 & 6 & 3 & 0 & 0 & 3 & 1 & 6 & 3 & 2 & 3 & 6 & 2 & 0 & 3 & 1 & 39 \\
\hline 01.05.19 & 3 & 0 & 0 & 6 & 3 & 3 & 0 & 0 & 3 & 0 & 3 & 3 & 3 & 0 & 0 & 27 \\
\hline 03.05.19 & 3 & 3 & 0 & 3 & 3 & 0 & 3 & 0 & 3 & 0 & 0 & 3 & 3 & 0 & 0 & 24 \\
\hline $\begin{array}{l}\text { Total } \\
\text { (Height) }\end{array}$ & 270 & 384 & 156 & 429 & 327 & 139 & 318 & 312 & 155 & 363 & 351 & 137 & 204 & 168 & 115 & 3828 \\
\hline Standart & & & & & & & & & & & & & & & & \\
\hline Error & 3.05 & 5.13 & 2.97 & 5.43 & 4.65 & 2.15 & 4.48 & 3.53 & 2.32 & 4.56 & 4.04 & 1.97 & 2.61 & 2.43 & 1.62 & 3.05 \\
\hline $\begin{array}{l}\text { Total } \\
\text { (Colors) }\end{array}$ & & 810 & & & 895 & & & 785 & & & 851 & & & 487 & & 220 \\
\hline
\end{tabular}

When the effectiveness of the different hues of blue colored traps were investigated, it was observed that the highest number of adults were captured in \#C4D5E3 (RGB=196.213.227) coded trap with 895 adults (Table 2). This trap was followed by \#4D9AC9, \#B4C8E1 and \#A6CDE3 coded traps. The lowest number of adults was captured in \#05467A coded trap, which was the darkest blue, with 487 adults. This darker hue of blue is similar to the traps used by farmers in the region against T. hirta, thus this result is found to be interesting. Yaşar et al.(2013) reported that the highest number of $T$. hirta adults was in light steel blue (RGB=198.222.255) colored funnel traps. The closest color in our study to the mentioned color is \#C4D5E3 (RGB=196.213.227), which had similarly high effectiveness at capturing $T$. hirta adults.

The results of the experiment to determine the effectiveness of the traps in different heights showed that, total number of the adults captured at ground level $(0 \mathrm{~cm}), 50 \mathrm{~cm}$ and $100 \mathrm{~cm}$ were 1584,1542 and 702 , respectively. While the numbers of adults captured at ground level and $50 \mathrm{~cm}$ height were pretty similar, the number of adults at $100 \mathrm{~cm}$ height was significantly lower than the others. This result was associated with the fact that the trees in the experimental orchard are 5 years old and are semi-dwarf, which may have created compatibility between the traps at ground level and $50 \mathrm{~cm}$ height. However, Çelik (2019) has reported the highest number of adults in cherry 
Özpınar \& Şahin \&Polat Comparison of Blue Basin Traps on Capturing The Adults of Tropinota hirta (Poda, 1761) (Coleoptera: Cetoniidae) at Three Different Heights in Cherry Orchards

orchards at $150 \mathrm{~cm}$ height, with no information about tree age or canopy height. The findings of the mentioned study do not match up with our results.

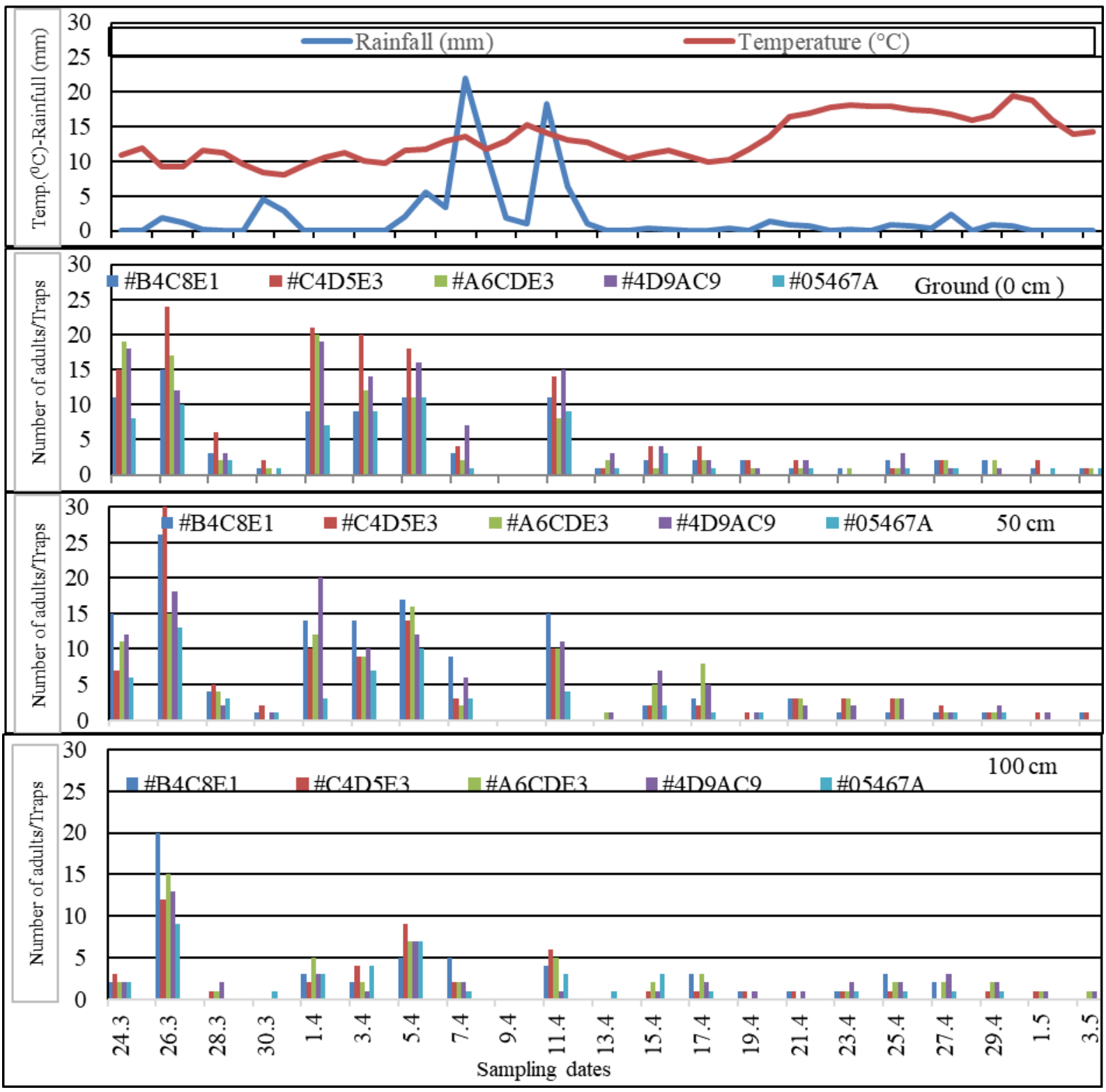

Figure 2. Population changes of Tropinota hirta adults captured in traps at three different heights in the cherry orchard.

On the other hand, the \#C4D5E3 coded trap has captured the most adults with 429 adults on the height with the most adults, which was ground level (Figure 3). This trap was followed by \#4D9AC9 coded trap with 363 adults. On $50 \mathrm{~cm}$ height, which had a total of 1542 adults, the highest number of adults was in the trap with the code \#B4C8E1 with 384 adults. This trap was followed by the \#4D9AC9 coded trap with 351 adults (Table 2 and Figure 3). The trap with the second highest number of adults captured on both ground level and $50 \mathrm{~cm}$ height, \#4D9AC9 coded trap, was the most effective in peach orchards (Erbay and Özpınar, 2019).

The difference between the numbers of $T$. hirta adults captured in traps was statistically significant with trap heights and colors in mind (Table 4). On ground level $(0 \mathrm{~cm})$, mean number of adults captured in different hues of blue was found to be significantly different $(\mathrm{P}<0.05)$. The highest number of adults was on the trap with the code \#C4D5E3, with a mean number of 7.15 adults. This trap was followed by the \#4D9AC9 coded trap with a mean number of 6.05 adults. The trap with the code \#05467A had significantly lower number of adults (3.40) than the other traps (Table 4). The difference between the number of adults on different hues of blue on $50 \mathrm{~cm}$ was also 
found to be statistically significant $(\mathrm{P}<0.05)$. The trap with the code \#05467A also had significantly lower number of adults (2.70) than the other traps on this height. The number of adults in the mentioned trap was found to be close to the number of adults caught in the dark blue traps from the study of Yaşar et al. (2013). The difference between the number of adults in the traps with different hues of blue was not statistically significant at $100 \mathrm{~cm}$ height $(\mathrm{P}>0.05)$.

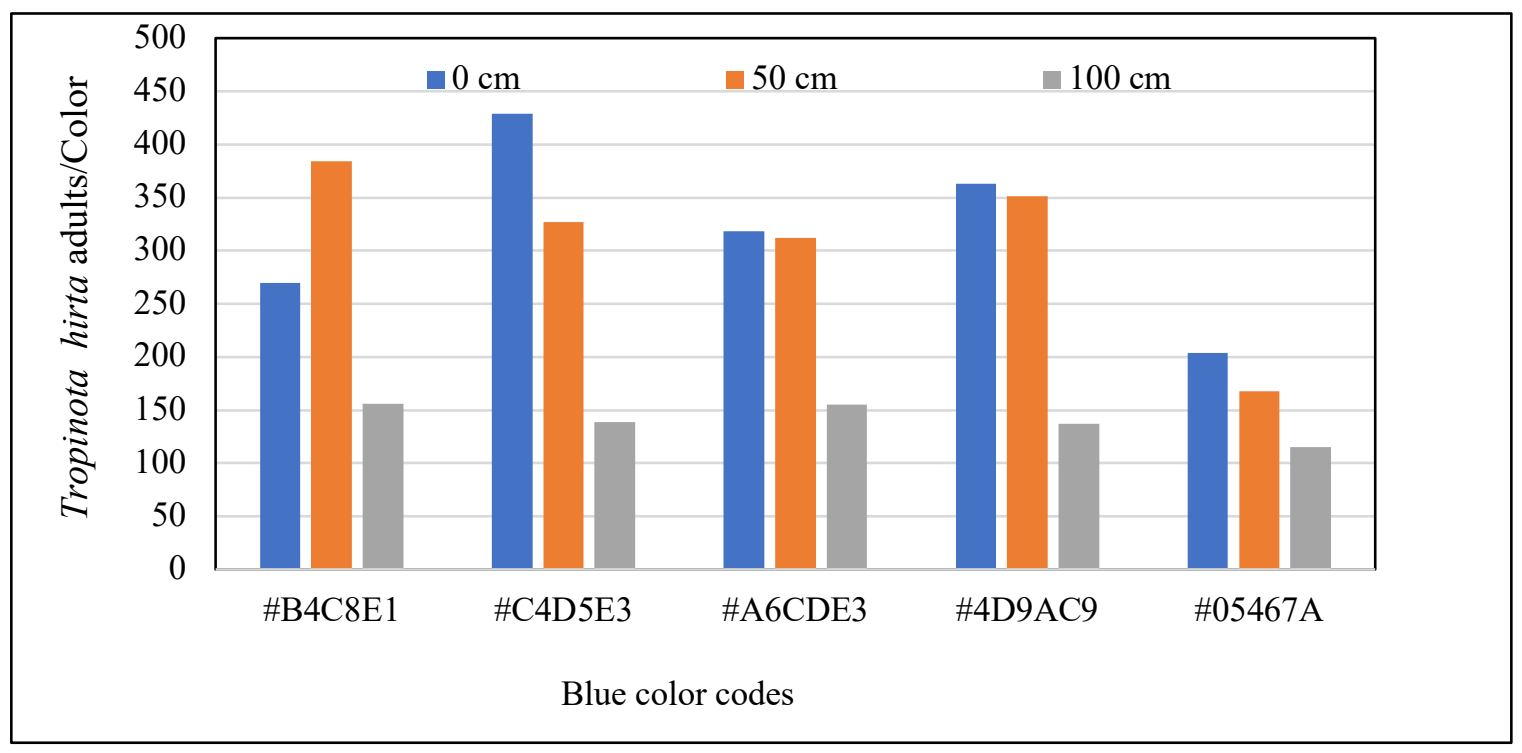

Figure 3. Total number of Tropinota hirta adults caught in different height traps in a cherry orchard.

Table 4. The mean number of Tropinota hirta adults in traps with different colors on three different heights (Mean \pm std error) $(n=60)$.

\begin{tabular}{|c|c|c|c|c|c|c|c|c|}
\hline $\begin{array}{c}\text { Hexadecimal } \\
\text { codes }\end{array}$ & \#B4C8E1 & \#C4D5E3 & \#A6CDE3 & \#4D9AC9 & $\# 05467 \mathrm{~A}$ & $\mathbf{F}$ & df (1-2) & $\mathbf{P}$ \\
\hline \multirow{2}{*}{$0 \mathrm{~cm}$} & $4.50 \pm 0.64$ & $7.15 \pm 1.06$ & $5.30 \pm 0.89$ & $6.05 \pm 0.89$ & $3.40 \pm 0.51$ & 2.297 & $4-295$ & 0.047 \\
\hline & b $\mathbf{A}$ & a $\mathbf{A}$ & b A & ab A & c $\mathbf{A}$ & & & \\
\hline \multirow{2}{*}{$50 \mathrm{~cm}$} & $6.40 \pm 0.98$ & $5.45 \pm 0.90$ & $5.20 \pm 0.72$ & $5.85 \pm 0.83$ & $2.85 \pm 0.49$ & 3.164 & $4-295$ & 0.014 \\
\hline & a $\mathbf{A}$ & a $\mathbf{A}$ & a $\mathbf{A}$ & a $\mathbf{A}$ & b $\mathbf{A}$ & & & \\
\hline \multirow{2}{*}{$100 \mathrm{~cm}$} & $2.60 \pm 0.61$ & $2.35 \pm 0.44$ & $2.65 \pm 0.45$ & $2.35 \pm 0.39$ & $1.95 \pm 0.34$ & 0.435 & $4-295$ & 0.078 \\
\hline & a $\mathbf{B}$ & a $\mathbf{B}$ & a $\mathbf{B}$ & a $\mathbf{B}$ & a $\mathbf{B}$ & & & \\
\hline $\mathbf{F}$ & 6.448 & 9.511 & 4,109 & 7.339 & 3.726 & & & \\
\hline df (1-2) & $2-177$ & $2-177$ & $2-177$ & $2-177$ & $2-177$ & & & \\
\hline $\mathbf{P}$ & 0.020 & 0.000 & 0.018 & 0.001 & 0,032 & & & \\
\hline
\end{tabular}

Note: The difference between the means with different small letters on the same row are statistically significant $(\mathrm{p}<0.05)$. The difference between the means with different capital letters on the column are statistically significant $(\mathrm{p}<0.05)$.

When the effectiveness of the traps at attracting the adults of T. hirta on different heights was compared, the difference between three heights on all traps was significant $(\mathrm{P}<0.05)$. The number of adults captured on ground level $(0 \mathrm{~cm})$ and $50 \mathrm{~cm}$ height was found to be not significantly different than each other, while the number of adults in the traps on $100 \mathrm{~cm}$ height was significantly different than the other heights $(\mathrm{P}<0.05)$. From these traps, the highest effectiveness was found on $50 \mathrm{~cm}$ height in the \#B4C8E1 coded trap, while ground level was found to be the most effective height for the \#C4D5E3 and \#4D9AC9 coded traps. The highest mean number of adults was captured in the trap with the code \#C4D5E3 with 7.15 adults per trap. However, the same coded trap was found to be on the $3^{\text {rd }}$ place at capturing $T$. hirta adults in peach orchards, while the trap on the $3^{\text {rd }}$ place in our study was the most effective at capturing adults in peach orchards (Erbay and Özpınar, 2019). These findings suggest that the attractiveness of the traps with different colors may vary with the fruit species. Yaşar and Dahham Dahham (2019) have reported that the different number of $T$. hirta adults captured with the same-colored traps on different apple cultivars may point to a link between trap color and cultivar. 


\section{Conclusions}

As a result of the study, different numbers of $T$. hirta adults were captured in the traps, which were placed on the orchard on March $22^{\text {nd }}$, with five different hues of blue on three different heights in a cherry orchard. The number of adults in the traps has varied with different heights on tested colors. The highest number of adults was captured in the \#C4D5E3 coded trap on ground level with 287 adults. This trap was followed by the \#B4C8E1 coded trap on $50 \mathrm{~cm}$ height with 256 adults. The \#4D9AC9 coded trap was in the $3^{\text {rd }}$ place on ground level with 247 adults. The lowest number of $T$. hirta adults was found in the \#05467A coded trap, which was the darkest blue hue in the study, on all heights. On all blue hues, the traps on $100 \mathrm{~cm}$ height were the least effective at capturing T. hirta adults. The height with the highest number of adults was ground level $(0 \mathrm{~cm})$. The success of basin traps on ground level is important for farmers because of their practicality. With these results in mind, there is a strong possibility to use \#C4D5E3 coded traps (Light grayish blue) successfully on ground level in cherry orchards against $T$. hirta adults in the future. 


\section{References}

Arslan, Ö. M., Aslan M. M. (2015). The activity of catching Epicometis hirta (Poda, 1761) (Coleoptera: Scarabaeidae) with different trap types on almond trees in Kahramanmaraş province. Kahramanmaraş Sütçü Imam University, Journal of Natural Sciences, 18(4): 6-12.

Aydın, G. (2011). Plant phenology-related shifts in color preferences of Epicometis (Tropinota) hirta (Coleoptera: Scarabaeidae: Cetoniinae) adults-key to effective population monitoring and suppression. Florida Entomologist, 94(4): 832-838.

Çelik, V. B. (2019). Isparta İli kiraz bahçelerinde farklı yerlere asılan mavi tuzakların Tropinota (Epicometis) hirta Poda, 1761 (Coleoptera; Cetoniidae)'nın yakalanması üzerine etkisi. (Master Thesis) Isparta University of Applied Sciences, Institute of Graduate Education. Isparta, Turkey, pp,34.

Doğan Öz, B., Saner, G. (2021) Determining the Investment perceptions of the cherry growing farms within support scheme for the purchase of agricultural machines and equipment (SSPME): A case of Izmir-Kemalpasa district. Journal of Tekirdag Agricultural Faculty 18(1):19.

Erbay, İ., Özpınar A. (2019). Determination of seasonal flight of Tropinota hirta (Poda) (Coleoptera: Cetoniidae) adults with different blue colour traps in peach orchards in Çanakkale province. Çanakkale Onsekiz Mart University, Journal of Agricultural Faculty, 7(2): 239247.

Gezer, B., Özpınar A. (2015). Çanakkale ilinde şeftali, elma, kiraz ve kayısılarda Tropinota hirta (Poda) (Coleoptera: Cetoniidae) ergin yoğunluğunu belirlemede farklı tuzakların değerlendirilmesi. Çanakkale Onsekiz Mart Üniversitesi, Ziraat Fakültesi Dergisi, 3(2): 2734.

Güvenç, C., Yaşar, B. (2014). Mavi renkli huni tuzaklarda kullanılan farklı cezbedicilerin kiraz çiçeklerinde beslenen Tropinota hirta (Poda) (Coleoptera: Scarabaeidae) erginlerinin yakalanması üzerine etkisi. Süleyman Demirel Üniversitesi, Fen Bilimleri Enstitüsü Derisi 18(3): 97-104.

Kara, K. (1992). Tropinata (Epicometis) hirta (Poda) (Coleoptera: Scarabaiidae)'nın Tokat ve çevresindeki konukçuları, yayılışı, zarar düzeyi, bazı biyolojik özellikleri üzerine araştırmalar. Gaziosman Üniversitesi, Ziraat Fakültesi Dergisi, 12(1): 15-26.

Kaya, M., Kovancı, B. (2004). Bursa'da ahududu alanlarında saptanan Coleoptera türleri. Ondokuz Mayıs Üniversitesi, Ziraat Fakültesi Dergisi, 19(3): $1-7$.

Kutinkova, H., Andreev, R. (2004). Integrated pest management in sweet cherry (Prunus avium L.) orchards in Bulgaria. Journal of Fruit and Ornamental Plant Research, 12: 41-47.

Özbek, H. (2008). Türkiye'de 1lıman iklim meyve türlerini ziyaret eden böcek türleri. Uludağ Arıcılık Dergisi, 8(3): 92-103.

Özpınar, A., Erbay, İ. (2020). Comparison of adult numbers of Tropinota hirta (Poda, 1761) (Coleoptera: Cetoniidae) captured with blue basin traps in two peach cultivars Harran Tarım ve Glda Bilimleri Dergisi, 24(3): 250-258.

Sağdaş, A. (2011). Farklı tuzakların Afyonkarahisar ili Sultandă̆ı ilçesinde kiraz ve elmalarda zarar yapan baklazınnı [Epicometis (=Tropinota) hirta Poda Coleoptera: Scarabaeidae)] 'nın yakalanması üzerine etkisi. (Master Thesis) Süleyman Demirel University, The Institute of Natural Sciences, Isparta, Turkey, pp,162.

Schmera, D., Toth, M., Subchev, M., Sredkov, I., Szarukan, I., Jermy, T., Szentesi A. (2004). Importance of visual and chemical cues in the development of an attractant trap for Epicometis (Tropinota) hirta Poda (Coleoptera: Scarabaeidae). Crop Projection, 23(10): 939-944.

Subchev, M., Toshova, T.B., Andreev, R.A., Petrova, V.D., Maneva, V.D., Spasova, T.S., Marinova, N.T., Minkov, P.M., Velchev, D.I. (2011). Employing floral baited traps for detection and seasonal monitoring of Tropinota (Epicometis) hirta (Poda) (Coleoptera: Cetoniidae) in Bulgaria. Acta Zoologica Bulgarica, 63(3): 269-276.

Toth, M., Klein, M.G., Imrei, Z. (2003). Field screening for attractants of scarab (Coleoptera: Scarabaeidae) pests in Hungary. Acta Phytopathologica at Entomologica Hungarica, 38(3-4): 323-331.

Vuts, J., Szarukán, I., Subchev, M., Toshova, T., Tóth, M. (2010). Improving the floral attractant to lure Epicometis hirta Poda (Coleoptera: Scarabaeidae, Cetoniinae). Journal of Pest Science, 83(1):15-20.

Yaşar, B., Çeşme, İ., Baydar, M.S., Aysal, İ., Yazır, A.B., 2013. Farklı mavi renkli huni tuzaklarının kiraz ağaçları çiçeklerinde beslenen bakla zınnı [Epicometis hirta (Poda) (Coleoptera: Scarabaeidae)]'nın yakalanması üzerine etkisi. Türkiye Entomoloji Bülteni, 3 (2): $99-105$.

Yaşar, B., Dahham Dahham, O.A., 2019. Farklı Elma Çeşitleri Üzerine Asılan Tuzakların Tropinota hirta (Poda, 1761) (Coleoptera: Cetoniidae) 'nın Yakalaması Üzerine Etkisi. Türkiye Tarımsal Araştırmalar Dergisi, 6(1): 57-64.

Zobar,, D., Kivan, M. (2019). Seasonal of Capnodis tenebrionis (L.) (Coleoptera: Buprestidae) on different chery rootstocks in orchards in Tekirdağ. Journal of Tekirdag Agricultural Faculty 16(3):339-347. 